\title{
Implementation of Competitive Intelligence in Improving Company Performance of Power Plant in Indonesia
}

\author{
Aldo Wijianto ${ }^{a}$, Ahmad Faishol Amin ${ }^{b}$, Tengku Mohd. Khairal Abdullah \\ a,b,c Business Management Program, Management Department, Binus Business School Master ProgramBina Nusantara \\ University, Jakarta, Indonesia, 11480 \\ a wijianto@binus.ac.id, ${ }^{\mathrm{b}}$ ahmad.amin@ binus.ac.id, ${ }^{\mathrm{c}}$ tabdullah@ @inus.edu *Corresponding Author
}

Article History: Received: 10 November 2020; Revised 12 January 2021 Accepted: 27 January 2021; Published online: 5 April 2021

\begin{abstract}
Numerous studies have been conducted on competitive intelligence and its impact on business performance. Most of companies agreed that competitive intelligence is a critical element of business and corporate strategy to increase income hence investment in competitive intelligence considered to be profitable. This research is aimed to expand the knowledge boundary by investigating the application of Competitive Intelligence in electrical power plant company. Twenty companies were selected as the target sample using purposive sampling design, in which the questionnaires were distributed to 120 individuals who were argued to have knowledge in the practice of Competitive Intelligence. In total, 105 questionnaires were returned for further analysis. Data were analyzed using descriptive statistic provided by SPSS. In the aspect of Competitive Intelligence Practices, results indicated that the mean score for each individual item range between 3.23 to 4.14, suggesting intensive practices of Competitive Intelligence. In the aspect of Utilization of Tools in practicing Competitive Intelligence, results indicated that three most widely used tools were from Employees, Customers and Internet. In the aspect of measurement variables in measuring competitive intelligence practices, results indicated that three most widely used measures were (1) yearly improvement of Equivalent Availability Factor-EAF (mean 3.96), (2) increase in percentage of planned maintenance (mean 3.82), and (3) yearly improvement of Equivalent Forced Outage Rate - EFOR (mean 3.75). Public utilities (infrastructure) company usually being pictured as companies that does not really care about competition as they usually being run by the Government. However, the findings of this research show otherwise.
\end{abstract}

Keywords:

\section{Introduction}

Today's economic growth and technological advancement have considerable impact on strategy modifications in companies, either in business-to-business (B2B) or business-to-customer (B2C) [1]. One of those strategies that has a major contribution to the development and sustainability of $\mathrm{B} 2 \mathrm{~B}$ companies is competitive intelligence (CI) [2]. In today's increasingly competitive business arena, companies compete and use strategies based on what they know, the speed at which individual firms learn and how well they have used them in the past, has a significant effect determining when to access resources such as capital, labor and materials [3]. A well-developed and welldesigned competitive intelligence system can assist a company in the strategic planning process, as well as facilitate in identifying objectives and capabilities of its competitors, and also determine the extent of risk that the company will face [4].

The electrical sector plays an imperative role in the development of a country production facilities (industrial, processing, agriculture, mining, education and health sectors) and furthermore as a factor in fulfilling people's daily social needs [5] [6] [7].

Numerous studies and research have been conducted on competitive intelligence and its positive impact on corporate business. The studies have shown that 78 percent of the companies agreed that competitive intelligence is a critical element of business and corporate strategy to increase income [8]. A survey by the Global Intelligence Alliance in 2011 revealed that despite changes in the world economy, nearly $70 \%$ of the companies plan to increase their competitive intelligence budget, as $94 \%$ of these companies agree that the competitive intelligence system provides benefits for the company. Also, the survey result related to the benefits of competitive intelligence, depicted that $84 \%$ approved investment in competitive intelligence as profitable, $13 \%$ considered it neutral and only $3 \%$ considered investment in this field as unprofitable [9].

In conducting studies and research regarding competitive intelligence on large companies, apart from the many challenges face, it also highlights opportunities that can be taken by either researchers or scholars. The toughest challenge face when conducting such research is the complexity of the problem and heterogeneity, but behind all 
that, great opportunities can be obtained, such as the exclusivity of such studies due to the limited research in this field [1]. In addition, studies related to competitive intelligence on companies providing infrastructure such as electric power plants, especially in developing countries, are somewhat limited. This particular circumstance, is most probably due to the nature of the industry in which the company operates, which is still a necessity and is less influenced by competition. This essentially increases the desirability of conducting studies related to companies in such developing industries.

\section{Literature review}

\section{Competitive Intelligence}

The term intelligence itself has already appeared in 500 B.C. and competitive intelligence (CI) has been used generally by military intelligence [10]. It is further explained that the word competitive intelligence was used even before 1980 in the United States as a formal term to express intelligence activities in gathering information for decision-making requirements [11]. CI was famous in the 1990s and has many meanings, both among scholars and researchers, as well as within the company [12]. The definition of CI is a process or practice that uses intelligence activities to carry out planning, ethics and legal collection, where information on the internal and external environment (competition environment) are processed and analyzed to help decision makers make strategic choices for the company.

\section{Aspects of Competitive Intelligence}

Competitive intelligence aspects consist of 4 parts [13], they are:

1. Commercial \& marketing intelligence covers customer's current trends, customer's want and need, new, innovative, and opportunity market segments; as well as changes and distribution that are taking place in the market.

2. Competitor intelligence includes the process of evaluating the competitive strategy of competitors in order to cope with changes of 14 competitors (e.g. structural changes, new products) and new competitors in the industry. Competitor aspects comprise objectives, strategies, strengths, weaknesses and reactions of competitors.

3. Technological intelligence contains evaluating the costs and benefits of using technology for the current or future business, along with evaluating future technological changes.

4. Strategic \& social intelligence encompasses individual knowledge of legal, financial, political, economic, social resources as well as availability of human resources.

\section{Competitive Intelligence Process}

Every implemented system certainly has a process practiced by a company. The Process of Competitive Intelligence (CI) is described as a circle to identify a continuous process that ends in a product development decision [14]. The process of implementation is divided into several steps, which includes planning and direction, information gathering, information filtering, information analysis, intelligence dissemination, decision making, processes and structures, organizational and cultural awareness, and feedback [2].

\section{Competitive Intelligence Framework}

Competitive Intelligence is a process or practice, which follows a predetermined phase [15]. The Competitive intelligence process is described as a continuous circle where the end product of one phase is the input of the next [14]. In business, competitive intelligence often uses a four-phase cycle model. Based on 20 years of business experience, the cycle of the four-phase CI model is much suitable and simpler, and application can be adapted to specific circumstances of government organizations. But current business practices face competitive intelligence globally with considerably more demanding task. These problems can be solved using a five-phase model of the competitive intelligence cycle [16]. There are influencing factors that play a role during the CI process [16]. The CI process consists of the following steps, depicted in the following Figure 1 below [17]. 


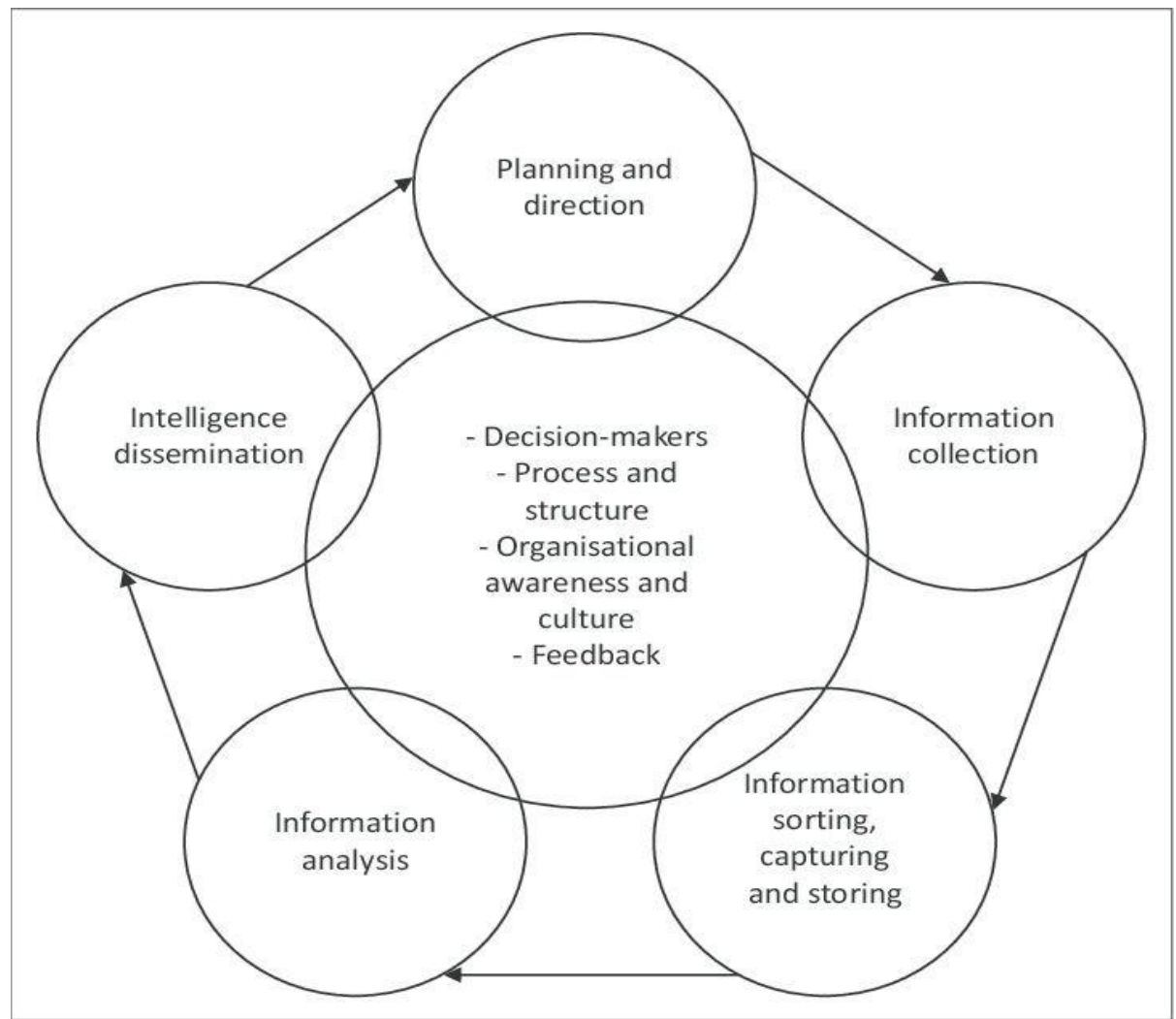

Figure 1. Competitive Intelligence Process Framework

\section{Operation and Maintenance Business Model of Power Plant}

Operation and maintenance business model is a business model offered by many companies, but tremendous differences exist between companies in that only doing operation is considered part of the outsourcing service offering [18]. The key success factors are shown in the three-dimensional model as depicted in Table 1 below (based on product offered, capabilities, customer and contract).

Table 1. Three-Dimensional Model Key to Success of Power Plant Management

\begin{tabular}{|c|c|c|}
\hline Offered & Capabilities & Custo \\
\hline $\begin{array}{l}\text { 1. Focus on learning the logic of } \\
\text { selling spare parts } \\
\text { 2. Strong reference needs. } \\
\text { 3. Direct feedback from the field } \\
\text { to R\&D. } \\
\text { 4. Customer segmentation } \\
\text { product offered. } \\
\text { 5. Health and environmental safety } \\
\text { considerations as part of the O\&M. }\end{array}$ & $\begin{array}{l}\text { 1. Measurable and robust IT and } \\
\text { process } \\
\text { 2. The presence of local HC / HR } \\
\text { 3. Need to have open access to } \\
\text { customers } \\
\text { 4. Balance remote-local mode } \\
\text { 5. Practice communication and } \\
\text { readiness }\end{array}$ & $\begin{array}{l}\text { 1. Mutually agreed governance } \\
\text { with KPI } \\
\text { 2. Delete account / contract } \\
\text { management } \\
\text { 3. CRM process and systems } \\
\text { focus } \\
\text { 4. Focus and pricing templates } \\
\text { and tools (including risk pricing) } \\
\text { 5. Produces logical clarity }\end{array}$ \\
\hline
\end{tabular}

Managing power plant is supported by carrying out very strategic, valuable and long duration of operations and maintenance activities [19]. This particular type of business model requires strategic level involvement from both parties. Power plant management activities depend on the ability to carry out operational and maintenance activities supported by skills in developing strategies used to improve the performance of the power plant unit. Therefore, the role of strategy formulation and governance is critical to the company's success in managing power plants. With proper management and adhering asset management standards, the plant will produce high operational performance and be recognized in the international standard for achieving power plant performance. Effective operation and maintenance management is one of the most cost-effective methods in ensuring reliability, safety and energy efficiency [20]. Inadequate maintenance of energy use systems is a major cause of energy waste in both the federal government and the private sector. Energy losses from steam, water and air leaks, non-isolated lines, non-adjustable or inoperable controls, and other disadvantages from poor maintenance are often enormous. Good maintenance practices can result in substantial energy savings and should be considered a resource. In addition, repairs to the facility maintenance program can often be done immediately and at relatively low cost. 


\section{Relationship Between Competitive Intelligence and Performance}

A significant number of small companies recognize competitive intelligence as essential to their operations, and practice it without realizing it [21]. As a result, in the United States, companies have formed specific divisions because they recognize how important competitive intelligence is in making the best strategic and tactical decisions. In short, studies on competitive intelligence are increasing, as demonstrated by many studies in various fields such as in strategic decision making [22], knowledge management [22] [23] [24], supply chain [24], information technology [25] [26], Innovation [27], entrepreneurial [28] and performance [29].

Companies collect information about competitors through a competitive intelligence process and apply it in decision making [30]. Competitive intelligence helps companies in making decisions by making businesses understand what they need to be competitive in the market [31]. In conclusion, empirical studies have shown a solid correlation between competitive intelligence as a source of competitive advantage and its contribution to firm's performance.

\section{Methodology}

The data collected for this study was conducted by a self-administered questionnaire adopted from the questionnaires developed by Nenzhelele [12]. The questionnaire was adapted into Indonesian language and distributed to the respondents to measure the implementation extent of Competitive Intelligence for the related company. Around 20 companies served under PT PJB Holdings were selected as sample due to the accessibility. Several types of power plants (Coal-fired, Diesel-fired, Gas-fired, Hydroelectric, Geothermal and Renewable Energy Power Plants) were identified as subsidiaries to the holding company were selected as sample of this research. Six respondents for each company were selected as respondents. These respondents were in managerial position and selected due to their knowledge in the use of Competitive Intelligence within their respective company. The sampling method used in this study was purposive, which is deemed appropriate for extracting information related to CI practitioners by interviewing the organizational managers in each area, selected by upper management, in implementing the power plant unit management policies, operation and maintenance. In the end, 105 questionnaires were returned for further analysis. Descriptive statistics was used to analyzed the data, which being processed using Statistical Package for Social Science Program (SPSS).

\section{Research Findings}

\section{Demographic}

Of the 105 respondents taking part in the survey, it was shown that $90.5 \%$ were male and the rest were female. As for the time range of respondents who work in the power plant unit, $49.5 \%$ have worked in between 6-10 years, $37.1 \%$ between $1-5$ years and $13.3 \%$ for more than 10 years. The distribution of respondents who participated in this survey consisted of $29.5 \%$ from maintenance, $27.6 \%$ from the operations, $23.8 \%$ from engineering and $19 \%$ from the administration. Judging from the capacity of the power plant where the respondent works, it indicated that $52.4 \%$ work in large plants, meaning more than $100 \mathrm{MW}, 10.5 \%$ from medium plants and $37.1 \%$ in small plants. The locations of power plant units of the respondents were spread from PLTMG Arun Aceh, PLTA Asahan North Sumatra, PLTU Banjarsari South Sumatra, PLTU Indramayu West Java, PLTU Rembang Central Java, PLTU Pacitan East Java, PLTU Paiton East Java, PLTU Kendari Sulawesi, PLTU Tidore Maluku, PLTU Amurang Sulawesi, PLTU Bolok Nusa Tenggara, PLTU Bangka South Sumatera, PLTU Tanjung Awar-Awar East Java, PLTU Tanjung Jati Central Java and several small power plants.

\section{The Practice of Competitive Intelligence in Power Plant Units}

The variables making up competitive intelligence practice are shown in Table 3. The average value of Variable 1 is 4.14 indicates that the majority of these power plant units are aware that CI is practiced. Variable 2 demonstrates an average value of 3.85 , signifying that the bulk of power plant units have implemented CI in managing the units. Variable 3 illustrates that the majority of power plant units employ other people or companies to collect information. Variable 4 specifies that most of the power plant units have official competitive intelligence procedures or processes. Variable 5 shows that the power plant units know their competitors. Variable 6 displays that the majority of power plant units have CI professionals. And from variable 7, the average value of 3.75 clarifies that the majority of the power plant units recognize the advantages and disadvantages of competitors.

The data of variable 8 shows that the majority of power plant units use information from competitors as material to analyze and prepare management strategies. From variable 9, it is discovered that the majority of power plant units know who are the customers of their competitors. In variable 10, it is found that the majority of power plant units know the prices and services that competitors offer to customers. And from variable 11, it is established that the majority of management in the power plant unit supports CI practices. 
Table 3. Variables for Competitive Intelligence Practice

\begin{tabular}{|l|l|l|l|}
\hline No & Variabel for Competitive Intelligence Practice & Mean & $\begin{array}{l}\text { Standard } \\
\text { deviation }\end{array}$ \\
\hline 1 & $\begin{array}{l}\text { We are aware that competitive intelligence is the process of gathering } \\
\text { information about competitors and the competitive environment, and apply it to } \\
\text { the decision-making and planning process for performance improvement. }\end{array}$ & 0.59 \\
\hline 2 & We implement competitive intelligence in our business. & 3.85 & 0.79 \\
\hline 3 & We employ other people or companies to collect information on our behalf. & 3.23 & 0.90 \\
\hline 4 & We have a formal competitive intelligence procedure or process. & 3.66 & 0.82 \\
\hline 5 & We know who our competitors are. & 4.10 & 0.68 \\
\hline 6 & We have competitive intelligent professional in our company. & 3.78 & 0.78 \\
\hline 7 & We know our competitor's strength and weakness. & 3.75 & 0.76 \\
\hline 8 & We collect information on our competitors and analyze the information & 3.76 & 0.80 \\
\hline 9 & We know who our competitors' customers are & 3.97 & 0.61 \\
\hline 10 & We know our competitors' product price and service & 3.55 & 0.87 \\
\hline 11 & Our management supports competitive intelligence practices & 0.73 \\
\hline
\end{tabular}

\section{Utilization of Tools in Competitive Intelligent Practice of Power Plant Units}

Table 4 indicates how information related to competitive intelligent practice is derived from. From the table, $53 \%$ of data related to CI are obtained from fellow employees. Finding this information is executed through teamwork activities or discussions with fellow employees during development of strategies related to management of power plant assets. 50\% is acquired from customers, such as PT PLN. Information is usually acquired during workshops held by PT PLN when preparing monthly operating plan. Information on competitive intelligence is also originated from the internet (48\%), suppliers (43\%) and other sources of information on CI, the rest is presented in Table 4 below.

Table 4. Sources of Information Related to Competitive Intelligence

\begin{tabular}{|l|l|}
\hline Competitive Intelligence Source of Information & Total Respondent \\
\hline From employees & 53 \\
\hline Customer & 50 \\
\hline Internet & 48 \\
\hline Supplier & 43 \\
\hline Company Report & 33 \\
\hline Senior Management & 30 \\
\hline Survey & 26 \\
\hline Consultant & 16 \\
\hline Magazine/Newspaper & 16 \\
\hline Exhibition & 13 \\
\hline Business Associates & 12 \\
\hline Interview & 9 \\
\hline Conference & 8 \\
\hline Social Media & 1 \\
\hline
\end{tabular}

Table 5 below displays the methods used to explore analysis tools applied by power plant unit in performing competitive intelligence. The most widely used methods / tools for analyzing competitive intelligence information 
are teamwork (61\%), SWOT Analysis (49\%) and brain storming. The other tools used in competitive intelligence of power plants are reported in table 4 , presented below.

Table 5. Use of Competitive Intelligence Information Analysis Tools

\begin{tabular}{|l|l|}
\hline $\begin{array}{l}\text { Methods I Tools of Competitive Intelligence } \\
\text { Information Analysis }\end{array}$ & Total Respondent \\
\hline Teamwork & 61 \\
\hline SWOT Analysis & 49 \\
\hline Brainstorming & 31 \\
\hline Statistics & 30 \\
\hline Macro environment analysis & 13 \\
\hline Value chainanalysis & 12 \\
\hline Financial ratio & 12 \\
\hline Valuation technique & 4 \\
\hline PESTEL & 2 \\
\hline
\end{tabular}

Table 6 below shows the method of presenting CI activities in power plant units. Most units use written reports (49\%), presentations (46\%), face to face (38\%), internal meetings $(36 \%)$, central database $(29 \%)$, internal application (28) internal audit (24\%) ) and reporting from email (13\%).

Table 6. Methods of Presenting Competitive Intelligence Results

\begin{tabular}{|l|l|}
\hline $\begin{array}{l}\text { Metode of Presenting Competitive } \\
\text { Intelligence Results }\end{array}$ & Total Respondent \\
\hline Written Report & 49 \\
\hline Presentation & 46 \\
\hline Face-to-Face Meeting & 38 \\
\hline Internal Meeting & 36 \\
\hline Central Database & 29 \\
\hline Internal Application & 28 \\
\hline Internal Audit & 24 \\
\hline Email & 13 \\
\hline
\end{tabular}

\section{Results of Competitive Intelligence Practice Measurement in Power Plant Units}

Table 7 below illustrates the results of CI implementation in power plant environment. Point 1 indicates that the majority of the percentage of planned work in power plant unit has increased. With CI implementation, information concerning management of power plant assets is related to maintenance plans to avoid any damage during operation. Point 2 shows that the majority of the number of equipment modifications and improvements in the units has increased. With information related to best practices or failure information from other power plants, the asset management company can plan the number of modified and improved equipment. Points 3, 4 and 5, confirm that when there is a significant increase in EA, disturbance decreases (EfOR), and SdOF of the units also decrease. Companies that implement CI will know and have a schedule and measurable data applied to support the operational activities of power plant units.

Table 7. Measurement variables of competitive intelligence practice

\begin{tabular}{|l|l|l|l|}
\hline No & Variable of Competitive Intelligence Practices & Mean & $\begin{array}{l}\text { Standard } \\
\text { Deviation }\end{array}$ \\
\hline 1 & Increase in percentage of planned maintenance & 3.82 & 0.80 \\
\hline 2 & Increase in total modification and improvement of tools & 3.70 & 0.79 \\
\hline 3 & Yearly improvement of Equivalent Availability Factor (EAF) & 3.96 & 0.87 \\
\hline
\end{tabular}




\begin{tabular}{|l|l|l|l|}
\hline 4 & Yearly improvement of Equivalent Forced Outage Rate (EFOR) & 3.75 & 0.96 \\
\hline 5 & Yearly improvement of Sudden Outage Frequency (SdOF) & 3.67 & 0.98 \\
\hline
\end{tabular}

\section{Discussion}

Electricity supply and power plant operations in Indonesia are primarily provided by the government, either through government or private agencies, cooperatives and non-governmental organizations, having receive permission from the government. Data realization have illustrated the continuous development of power plant capacity outside the state owned electricity company, commonly known in Indonesia as Perusahaan Listrik Negara (PLN), where recent construction of private ownership new power plants has become more dominant, while PLN's capacity is relatively constant. Considering that the need for electricity supply in Indonesia is relatively high, meeting this amount of energy will become a competition for power plant management companies to provide the finest. In addition to captive power plants (plants for industrial consumption), almost all power plant in Indonesia are connected to PLN, in essence the customer is none other than PLN, who will consequently buy electrical energy produced by those power plants.

Although the power plant unit management industry is still dominated by the government, the majority of power plant units have formally practiced CI. Power plant units employs a person or organization to gather information for competitive intelligence. The role of $\mathrm{CI}$ is utilized by these power plant units to seek information on strategies in how best to manage power plants. These power plant units know who their competitors' suppliers are so they can ensure they are not overpay their competitors for the same raw material. Power plant units in Indonesia generally do not employ CI professionals, thus no such division of this function is designated. Power plant units also know the strengths and weaknesses of their competitors, thus information helps in strategic planning. The majority of power plant units know their competitors' customers, as well as the prices of their competitors' products and services, so as to ensure that the pricing of product or service are done competitively.

Most power plant units collect information for CI from fellow employees, customers, suppliers, the internet, company reports, senior management and surveys. Employees and customers are the main sources of CI information within the electric power plant sector. This could be because they are in close contact with fellow employees and customers on a daily basis. The majority of these power plant units generally utilize teamwork, brainstorming, SWOT analysis, and statistical analysis to examine information on competitive intelligence. In particular, teamwork and brainstorming are the most extensively used analytical methods for generating actionable intelligence. While SME power plant units commonly use written reports, presentations, face-to-face meetings and internal meetings to disseminate actionable intelligence. Thus, written reports and presentations are the most widely used methods of transmitting CI.

The implementation of $\mathrm{CI}$ in power plant units has a substantial impact on increasing maintenance but also reinforce improvement on operational performance such as: Equivalent Availability Factor (EAF), Equivalent Forced Outage Rate (EFOR), and Sudden Outage Frequency (SdOF).

\section{Conclusion}

Essentially the majority of electric power plant units in Indonesia have officially practiced competitive intelligence. Power plant units employ a person or organization to collect information for competitive intelligence; obtaining information on competitors' strengths and weaknesses, suppliers, customers, prices of products or services and seek information on strategies for best practice managing electric power plant units. Information is collected from fellow employees, customers, suppliers, the internet, company reports, senior management and surveys. However, customers and fellow employees remains the main sources of information. Information collected are mainly analyzed through teamwork, brainstorming, SWOT analysis, and statistical analysis. The results of actionable analysis are disseminated to decision-makers through written reports, presentations, face-toface meetings and internal meetings. Making implementation of competitive intelligence in the majority of power plant units impactful in increasing planned maintenance and progress, hence improving operational performance in: Equivalent Availability Factor (EAF), Equivalent Forced Outage Rate (EFOR), and Sudden Outage Frequency (SdOF).

Overall, the benchmark to see the success of competitive intelligence practice implementation is usually through periodic evaluations, where measurement of power plant performance is conducted. Commonly, it is measured every month, quarter, semester and annually. Future research should be conducted to measure the extent of the relationship between competitive intelligence and operational performance of power plant and what are the underlying influential factors 


\section{References}

G. L. Lilien, "The B2B Knowledge Gap," International Journal of Research in Marketing Volume 33. Issue 3., pp. 543-556, 2016.

T. E. Nenzhelele and R. Pellissier, "Competitive Intelligence Implementation Challenges of Small and MediumSized Enterprises," Mediterranean Journal of Social Sciences, vol. 5, no. 16, p. 92, 2014.

C. S. Fleisher and B. E. Bensoussan, Strategic and Competitive Analysis: Methods and Techniques for Analyzing Business Competition, Upper Saddle River: Prentice Hall, 2003.

M. Gross, "Competitive Intelligence: A Librarian's Empirical Approach," Searcher: The Magazine for Database Professionals, vol. 8, pp. 70-76, 2000.

W. Wallace, "From Indonesia 2008 to Indonesia 2012 and beyond Where Things Stand and the Challenges Ahead," Washington DC, 2008.

Z. Arief, "Pelaksanaan Tender dalam Pembangunan Infrastruktur," in Seminar Hukum Nasional, Jakarta, 2011.

L. Adam, "The Roles and Problems of Infrastructure in Indonesia," Ekonomi dan Keuangan Indonesia , vol. 60, no. 1, p. 105, 2015.

S. D. Kilmetz and R. S. Bridge, "Gauging the returns on investments in Competitive Intelligence: A three-step analysis for executive decision makers," Competitive Intelligence Review, vol. 10, no. 1, pp. 4-11, 1999.

Global Intelligence Alliance, "Market Intelligence in Global Organizations: Survey Findings in 2011," Global Intelligence Alliance, 2011.

P. T. Adidam, . M. Banerjee and . P. Shukla, "Competitive Intelligence and Firm's Performance in Emerging Markets: an Exploratory Study in India," Journal of Business \& Industrial Marketing, vol. 27, no. 3, pp. 242$254,2012$.

M. Begg and A. Du Toit, "Level of Importance Attached to Competitive Intelligence at a Mass Import Retail Organization," South African Journal of Information Management, vol. 9, no. 4, pp. 1-19, 2007.

T. E. Nenzhelele, "Competitive Intelligence Tools Used by Small and Medium-sized Enterprises," Journal of Governance and Regulation, vol. 4, no. 3, 2015.

D. Rouach and P. Santi, "Competitive Intelligence Adds Value: Five Intelligence Attitudes," European Management Journal, vol. 19, no. 5, pp. 552-559, 2001.

J. Calof and B. Skinner, "Competitive Intelligence for Government Officers: A Brave New World," Optimum, vol. 28, no. 2, pp. 38-42, 1998.

A. Du Toit and N. Sewdass, "A comparison of competitive intelligence activities in Brazil, Malaysia, Morocco and South Africa," Acta Commercii, vol. 14, no. 1, pp. 1-7, 2014.

F. Bartes, "Denying a Basis for The New Concept of Competitive Intelligence," ACTA University Agriculturae ET Silviculturae Mendelianae Brunensis, vol. 62, no. 6, p. 1233-1242, 2014.

R. Pellissier and T. Nenzhelele, "Towards a Universal Compeve Intelligence Process Model," South African Journal of Information Management, vol. 15, no. 2, pp. 1-7, 2013.

H. Hyvönen, "Operations \& Maintenance Business Model Transformation Multiple Case Studies," Modern Economy, vol. 5, pp. 1161-1170, 2014.

Z. Zhu, K. Hsu and J. Lillie, "Outsourcing - A Strategic move: The Process and The Ingredients for Success," Management Decision, vol. 39, no. 5, pp. 373-378, 2001.

G. Sullivan, . R. Pugh, A. P. Melendez and W. D. Hunt, "Operations \& Maintenance Best Practices - A Guide to Achieving Operational Efficiency (Release 3)," Pacific Northwest National Lab, United States, 2010.

A. Persidis, "Corporate intelligence in a Corporately Intelligent World.," Journal of Competitive Intelligence and Management, vol. 1, no. 2, pp. 87-99, 2003.

A. Du Toit, "Competitive Intelligence In The Knowledge Economy: What is In It for South African Manufacturing Enterprises?," International Journal of Information Management, vol. 23, no. 2, pp. 111-120, 2003.

M. Franco, A. Magrinho and S. Ramos, "Competitive Intelligence: A Research Model Tested on Portuguese Firms," Business Process Management Journal, vol. 17, no. 2, pp. 332-356, 2011.

N. Jaharuddin, Z. D. Mansor and S. Yaakob, "Assessing the Supply Chain Intelligence Practices of Small Medium Enterprises in Malaysia," Procedia Economics and Finance, vol. 35, pp. 515-521, 2016.

P. Dishman and J. Calof, "Competitive Intelligence: A Multiphasic Precedent to Marketing Strategy," European Journal of Marketing, vol. 42, no. 7/8, pp. 766-785, 2008.

T. S. Teo and W. Y. Choo, "Assessing The Impact of Using The Internet for Competitive Intelligence," Information and Management, vol. 39, no. 1, pp. 67-83, 2001.

P. Nemutanzhela and T. Iyamu, "A Framework for Enhancing The Information Systems Innovation: Using Competitive Intelligence," The Electronic Journal of Information Systems, vol. 14, no. 2, 2011.

T. Qiu, "Scanning for Competitive Intelligence: A Managerial Perspective," European Journal of Marketing, vol. 42, no. 7/8, pp. 814-835, 2008. 
J. J. JMcGonagle and C. M. Vella, "Competitive Intelligence In Action," IEEE Engineering Management Review, vol. 36, no. 3, p. 12, 2004.

P. Hawking and C. Sellitto, Business intelligence strategy: a utilities company case study. Business Intelligence: Concepts, Methodologies, Tools, and Applications: Concepts, Methodologies, Tools, and Applications, USA: Information Resources Management Association, 2015.

W. Fan and M. D. Gordon, "The Power of Social Media Analytics," Communications of the ACM, vol. 57, no. 6, pp. 74-81, 2014. 